\title{
Response of anchovies dampens effects of the invasive bivalve Corbula amurensis on the San Francisco Estuary foodweb
}

\author{
W. J. Kimmerer* \\ Romberg Tiburon Center, San Francisco State University, 3152 Paradise Drive, Tiburon, California 94920, USA
}

\begin{abstract}
Introduced bivalves have suppressed phytoplankton production in many aquatic foodwebs, but effects on higher trophic levels have been inconsistent. In the northern San Francisco Estuary, the introduced clam Corbula amurensis eliminated summer-long phytoplankton blooms starting in 1987, but responses of mesozooplankton biomass and most fish were somewhat muted. I conducted a retrospective analysis of the response of the estuarine foodweb to the decline in phytoplankton due to clam grazing. When $C$. amurensis invaded, the distribution of northern anchovy Engraulis mordax shifted toward higher salinity, reducing summer abundance by $94 \%$ in the lowsalinity region of the estuary. Northern anchovy dominates the biomass of fish in the more saline reaches of the estuary, and is genetically affiliated with the subpopulation on the central California coast, which in turn is strongly influenced by climate variability. However, abundance of northern anchovy within the estuary was not related to available estimates of biomass, catch, or abundance of northern anchovy on the California coast, nor was it related to any of 4 variables describing aspects of climate variability with different time and space scales. The shift in spatial distribution appears to have been a direct behavioral response to reduced food. Bioenergetic calculations showed reduced consumption of zooplankton by all planktivores, including mysids, after $C$. amurensis became abundant and the anchovy left the low-salinity region of the estuary. This reduced consumption appears to have mitigated effects of the loss of phytoplankton productivity, making a greater proportion of the zooplankton productivity available to other fish species. Such behavioral accommodations are likely wherever invasions occur in open systems.
\end{abstract}

KEY WORDS: Estuary · Anchovy $\cdot$ Foodweb $\cdot$ Introduced species Resale or republication not permitted without written consent of the publisher

\section{INTRODUCTION}

Studies of natural ecosystems must often apply indirect or reductionist approaches to elucidate ecosystem-scale mechanisms, since many ecosystems are inaccessible to experiment. Although whole-lake experimental manipulations have proved fruitful (Carpenter et al. 1995), many aquatic systems are not amenable to manipulation. In these systems, responses to natural or human-induced perturbations can be useful for examining complex processes at the ecosystem level. Species introductions can perturb an aquatic ecosystem, resulting in an inadvertent and uncontrolled experiment. Several invasions of aquatic sys- tems by bivalves have provided opportunities to learn about ecosystem processes, particularly where investigations were underway before the invasions. The most notable of these have been the invasions of lakes and rivers in North America and Europe by the zebra mussel Dreissena polymorpha (Strayer et al. 2004) and the invasion of the San Francisco Estuary by the clam Corbula amurensis (Alpine \& Cloern 1992, as Potamocorbula amurensis, see Coan 2002).

Reductions of phytoplankton biomass by bivalve grazing in shallow aquatic ecosystems are well documented (Cloern 1982). Bivalves are 'ecosystem engineers' (Jones et al. 1994) that can increase water clarity by filtering fine particles, transport organic 
matter from the water column to the sediment, create physical habitat, and facilitate the spread of other species (Vanderploeg et al. 2002). Bivalve grazing may also have indirect effects, such as through release of nutrients from control by phytoplankton resulting in higher phytoplankton growth rates (Prins et al. 1998), or through a shift in size distribution of consumed organisms.

In spite of the strong effects of bivalves in suppressing phytoplankton and other small organisms, experimental and field studies and long-term monitoring have found complex and rather unpredictable responses of pelagic foodwebs to introduced bivalves (Noonburg et al. 2003). For example, responses of foodweb components not directly consumed by zebra mussels have been subtle or non-detectable in invaded lakes (Gonzalez \& Downing 1999), and yellow perch populations increased following a zebra mussel invasion (Mayer et al. 2000).

The San Francisco Estuary (SFE) has been heavily influenced by introduced species. The best-documented invasion was that by Corbula amurensis, which became abundant in 1987. This clam has apparently had an overwhelming impact on phytoplankton in the northern, river-dominated estuary, particularly in summer in Suisun Bay (Fig. 1), a broad, shallow, brackish reach of the estuary (Alpine \& Cloern 1992, Thompson 2000). Before the invasion of C. amurensis, summer-long periods of high phytoplankton biomass occurred in all years except during a drought in 1976-1977, when the marine clam Mya arenaria settled in Suisun Bay in sufficient numbers to suppress phytoplankton (Nichols 1985). Much of the decline in summer phytoplankton has been in diatom biomass, and the linkage between this decline and the introduc-

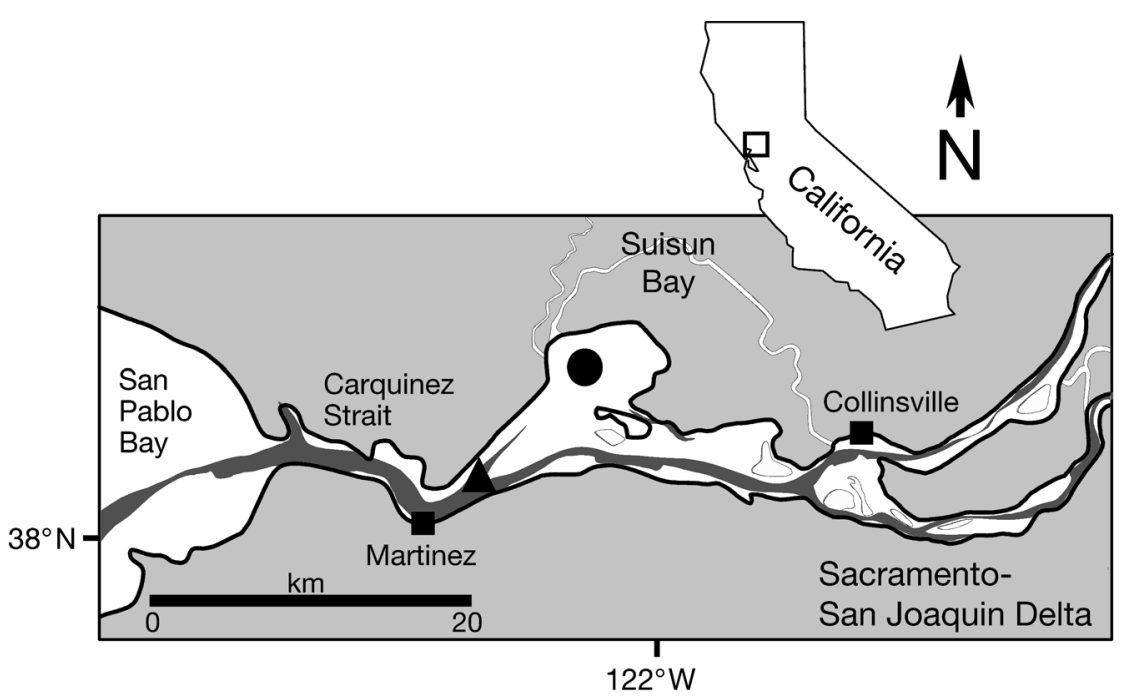

Fig. 1. Map of the northern San Francisco Estuary. Squares: continuous monitoring stations for salinity. Triangle and circle: benthic monitoring stations tion of C. amurensis is strong, with minor influences of freshwater flow and temperature, and no effects of nutrient supply (Jassby et al. 2002, Kimmerer 2005).

In contrast to findings from other systems (e.g. Phelps 1994), Corbula amurensis had no significant impact on water clarity, which is principally controlled by the concentration of mineral particles (Jassby et al. 2002). Since phytoplankton production in the northern estuary is generally limited by light rather than nutrients (Cloern et al. 1983), production is unlikely to have been stimulated by accelerated release of nutrients (Prins et al. 1998), and no such stimulation has been reported.

Despite the sharp reduction in phytoplankton biomass and production in this region, responses of the foodweb have been inconsistent. A decline in abundance of the copepod Eurytemora affinis after 1987, attributed to reduced food and consumption of nauplii by clams, was followed by the appearance of another calanoid copepod, Pseudodiaptomus forbesi, so total calanoid copepod abundance changed very little (Kimmerer \& Orsi 1996). In addition, the small cyclopoid Limnoithona tetraspina, introduced in 1993, became the most abundant copepod in this area (Orsi \& Ohtsuka 1999). Mysid abundance declined sharply, and 3 species of estuarine-dependent fish declined, but others maintained their abundance following the clam invasion (Kimmerer 2002).

In an effort to understand the inconsistent response of the estuarine foodweb to Corbula amurensis, I conducted a retrospective analysis of several rich, longterm data sets from the San Francisco Estuary. The focus of this analysis was summer (June-October) in the low-salinity ( 0.6 to $10 \mathrm{psu}$ ) region of the estuary, which corresponds roughly to the western Sacramento-San Joaquin Delta and eastern Suisun Bay (Fig. 1). Phytoplankton biomass in this region has been heavily influenced by $C$. amurensis (Jassby et al. 2002), and many estuarine-dependent fish species rear and begin to feed in this region (Kimmerer 2002). The objective of this analysis was to reconstruct changes in the foodweb following the invasion by $C$. amurensis to determine why changes in some of the functional groups were so muted. The general approach was to determine the magnitudes of step changes in biomass and production or consumption of major functional groups around 1987-1988, in the context of other temporal variability.

The particular focus of this study was on the changing trophic role of north- 
ern anchovy Engraulis mordax as the biomass-dominant planktivore in the estuarine foodweb. Northern anchovy is abundant along the west coast of North America from southern Canada to the Sea of Cortez. The population in the SFE is associated with the central of 3 genetically distinct subpopulations along the west coast (Vrooman et al. 1981). Abundance patterns of anchovy and sardine generally are inversely related and tied to climate conditions in several regions of the world including the northeast Pacific (Lluch-Belda et al. 1992, Schwartzlose et al. 1999). Therefore I examined the possible roles of climate variability and variation in the abundance of the coastal populations of both northern anchovy and Pacific sardine Sardinops sagax in influencing variability of anchovy within the estuary. I also examined catch data from the coastal ocean; anchovies are caught in the bay only as bait and catch statistics are unavailable.

\section{MATERIALS AND METHODS}

Data sources. Most data for the SFE were obtained from monitoring programs of the Interagency Ecological Program for the San Francisco Estuary (Table 1). Freshwater flow into the estuary is calculated daily, and salinity and temperature are monitored continuously at several locations (Fig. 1). Discrete samples are taken in a water quality and phytoplankton program (Lehman 2000), a zooplankton monitoring program (Orsi \& Mecum 1986), the San Francisco Bay study (Armor \& Herrgesell 1985) which monitors abundance of shrimp and young fish, and a midwater trawl pro- gram for young fish in the fall (Moyle et al. 1986). Each of these programs also measures temperature and either conductivity or salinity. I used surface values taken throughout each of these programs. Additional data on weight of several zooplankton species, lengthweight data for mysids, and biomass of shrimp were obtained from K. Hieb and L. Mecum (California Department of Fish and Game).

Phytoplankton data were obtained as chlorophyll concentration. Zooplankton data were obtained as abundance $\mathrm{m}^{-3}$ by species or higher taxonomic grouping for 3 size classes (Orsi \& Mecum 1986). For this study I used data on rotifers, copepods, and mysids, respectively the most abundant taxa in the 3 size classes. The San Francisco Bay study (Armor \& Herrgesell 1985) took samples for fish and large crustaceans at 35 to 52 stations, monthly during 1980 to 2002 except in winter months in some years since 1989, using both an otter trawl and a midwater trawl, each equipped with a flowmeter. All fish and caridean shrimp were identified to species, and either all individuals or a random sample of 50 of each species per trawl were measured to the nearest $\mathrm{mm}$. Data were reported as numbers per tow, which were converted to numbers $\mathrm{m}^{-3}$ using reported volume per tow for the midwater trawl, and area per tow times the mean depth of Suisun Bay $(3 \mathrm{~m})$ for the otter trawl. Similar calculations were made for the fall midwater trawl.

Data on abundance of northern anchovy in the coastal ocean were obtained for comparison with abundance at high salinity in the estuary. Spawning biomass was estimated from egg abundance for 1963 to 1995 (Jacobson et al. 1995). Catch data for an-

Table 1. Sources of data used in this paper. Abbreviations: IEP: Interagency Ecological Program for the San Francisco Estuary; DFG: California Department of Fish and Game; DWR: California Department of Water Resources; USGS: U.S. Geological Survey; NOAA: National Oceanic and Atmospheric Administration. All agency sampling programs in the estuary take basic water quality measurements such as salinity, temperature, and Secchi depth

\begin{tabular}{|c|c|c|c|}
\hline Data & Agency & URL or source & Comments \\
\hline Freshwater flow & IEP/DWR & www.iep.ca.gov/dayflow/index.html & Net Delta Outflow \\
\hline Irradiance & Integrated Pest Management & www.ipm.ucdavis.edu/ & \\
\hline Chlorophyll & IEP/DWR, DFG & http://baydelta.ca.gov/ & \\
\hline Chlorophyll & USGS & http://sfbay.wr.usgs.gov/access & \\
\hline Zooplankton & IEP/DFG & $\begin{array}{l}\text { L. Mecum, DFG, pers. comm. } 4001 \text { N. } \\
\text { Wilson Way, Stockton CA } 95205\end{array}$ & $\begin{array}{l}\text { Net }(>150 \mu \mathrm{m}) \text { and pump }(45- \\
150 \mu \mathrm{m}) \text { samples separately }\end{array}$ \\
\hline Fish & IEP/DFG & http://baydelta.ca.gov/ & $\begin{array}{l}\text { San Francisco Bay Study and } \\
\text { Fall Midwater Trawl Study }\end{array}$ \\
\hline Benthos & IEP/DWR & http://baydelta.ca.gov/ & \\
\hline PDO & U. of Washington & ftp://ftp.atmos.washington.edu/mantua/ & Pacific Decadal Oscillation \\
\hline MEI & NOAA & www.cdc.noaa.gov/ & Multivariate ENSO Index \\
\hline Upwelling & NOAA & www.pfeg.noaa.gov/products/pfel/ & Index for $39^{\circ} \mathrm{N}$ latitude \\
\hline $\begin{array}{l}\text { Sea surface } \\
\text { temperature }\end{array}$ & NOAA & www.cdc.noaa.gov/cdc/data.noaa.ersst.html & $\begin{array}{l}\text { Extended Reconstructed SST } \\
\text { for } 38^{\circ} \mathrm{N}, 122^{\circ} \mathrm{W}\end{array}$ \\
\hline Salinity & IEP/DWR & http://baydelta.ca.gov/ & Continuous monitoring site \\
\hline
\end{tabular}


chovy and Pacific sardine fisheries were obtained from the California Department of Fish and Game (CDFG 2002, 2003). In addition, catch data for northern anchovy in the coastal ocean near the mouth of San Francisco Bay were obtained as bycatch in a rockfish survey (Ralston \& Howard 1995, S. Ralston, NOAA, pers. comm.). Data used were from stations on the inshore $30 \mathrm{~km}$ of each transect between $36^{\circ} 20^{\prime}$ and $38^{\circ} \mathrm{N}$ latitude, where anchovies were found consistently.

Climate data included freshwater flow, the Pacific Decadal Oscillation (PDO) index (Mantua et al. 1997), multivariate El Niño Southern Oscillation (ENSO) index (Wolter \& Timlin 1993), coastal upwelling indices for $36^{\circ} \mathrm{N}$ and $39^{\circ} \mathrm{N}$ (Bakun 1990), and reconstructed sea surface temperature for $38^{\circ} \mathrm{N}, 122^{\circ} \mathrm{W}$ (Smith \& Reynolds 2003).

Data analyses. I estimated biomass for each taxon and for common species within taxa for the pre-and post-clam periods. The various monitoring programs differed in time span and some samples were missed. To keep data comparable among functional groups I used only those years and months when data were available from all studies for the low-salinity zone. All data were calculated as means for summer in a salinity range of 0.6 to 10 psu. Biomass of phytoplankton was calculated from chlorophyll using a carbon:chlorophyll ratio of 30 (Jassby et al. 2002). Biomass of rotifers was estimated using carbon per individual by genus (species are not determined) from literature sources (Hutchinson 1982, Walz 1995). Carbon biomass of copepods was measured for adult females of the principal calanoids Eurytemora affinis and Pseudodiaptomus forbesi using a Europa mass spectrometer (Bouley \& Kimmerer 2006, this volume), and estimated for the small cyclopoid Limnoithona tetraspina using a length-weight relationship for Oithona davisae (Uye 1982). All these estimates were for adult male and female copepods; copepodites are not identified to stage in the sampling program, so a nominal stage III was assumed, and weight of each copepodite was determined using ratios to adult weight from the literature for the same or similar species (generally 0.13 to 0.28, Burkill \& Kendall 1982, Klein Breteler et al. 1982, Uye et al. 1983, Kimmerer \& McKinnon 1987). Biomass of nauplii was not included in the analysis.

Dry weight of the mysid Neomysis mercedis was determined at $1 \mathrm{~mm}$ length intervals from 2 to $16 \mathrm{~mm}$ and the log length to log weight relationship was extrapolated linearly to $18 \mathrm{~mm}$ to account for mysids larger than $16 \mathrm{~mm}$ ( $6 \%$ of the total). Dry weight of Acanthomysis spp. was calculated using the same relationship. Dry weight of zooplankton and mysids was converted to carbon using a carbon:dry weight ratio of $40 \%$ (Uye 1982). Wet weight biomass of caridean shrimp was provided by K. Hieb (pers. comm.) and converted to carbon using a ratio of $8 \%$ (Ricciardi \& Bourget 1998).

Biomass of fish was determined using length to weight relationships by species either from measurements on $\sim 6000$ fish in the estuary or from literature values (Kimmerer et al. 2005a). Wet weight was converted to carbon assuming $50 \%$ dry:wet weight and $30 \%$ carbon:dry weight based on data summarized by Hanson (1997). Only fish smaller than $182 \mathrm{~mm}$ (99th percentile of length) were included because fish larger than that were caught sporadically and occasional catches of very large fish distorted the biomass estimates. Bias and variability associated with estimating biomass from these relationships are small compared to sampling variability.

The 2 midwater trawl data sets were used to analyze abundance patterns of northern anchovy, all for the summer dry season (June-October). The data were divided into 3 salinity ranges: high $(\mathrm{S}>20 \mathrm{psu})$, medium $(20 \geq \mathrm{S}>10 \mathrm{psu})$, and low $(10 \geq \mathrm{S}>0.6 \mathrm{psu})$, corresponding to approximate ranges of abundance of anchovy. For example, over all years anchovies comprised $93 \%$ (median) of the summer biomass in the high-salinity region, $90 \%$ in the medium-salinity region, and $38 \%$ in the low-salinity region. The fall midwater trawl survey extends only as far seaward as San Pablo Bay, and during high-flow periods at most a few samples were taken in the high-salinity region. Anchovy catch per trawl, with 1 added to allow zero catches to be included, was averaged among all stations and log-transformed for analysis. The ratio of mean catch in the low-salinity region to that in the high-salinity region was log-transformed to determine geometric means and confidence limits by time period for each survey.

The basic model for this analysis was a linear regression of log-transformed abundance or biomass on a step function occurring between 1987 and 1988; the timing of this step has been tested using regression trees for several estuarine-dependent species, although rotifers and mysids declined 2 yr later (Kimmerer 2002). Abundances of several fish and invertebrate taxa vary positively with freshwater flow (Jassby et al. 1995). Flow had no long-term trend, but introduced some error variance into simple analyses of temporal changes in abundance or biomass. I therefore constructed linear models of the log of biomass as a function of the $\log$ of freshwater flow and a step change between 1987 and 1988. Results for each taxon are reported as follows: I determined the partial residual for the step change only, then added the grand mean to this term to get a partial residual in units like the original. This result is equivalent to the pre- and post-clam means with the effects of flow removed. 
Anchovy abundance was tested using similar models without the flow effect.

Production or consumption rates were estimated for a subset of taxonomic groups for which reasonable growth rate estimates could be made. Phytoplankton net primary production was calculated from chlorophyll, irradiance, and light extinction coefficients (Cole \& Cloern 1984, Jassby et al. 2002). Extinction coefficient is not measured routinely, but secchi depth was reported from all stations in the IEP water-quality monitoring program, and depth of the $1 \%$ light level was reported for 4639 samples. This was converted to extinction coefficient $k\left(\mathrm{~m}^{-1}\right)$, which was then estimated for all samples by regression on 1 / secchi depth (m). Because variance of the data was heterogeneous I used a generalized linear model with linear link function and variance proportional to mean squared (Venables \& Ripley 1997). The resulting regression was $k=0.36+(0.60 \pm 0.01) / \operatorname{secchi}(95 \% \mathrm{CL})$, and the standard deviation of residuals was $0.47 \mathrm{~m}^{-1}$.

Zooplankton and mysid production was calculated without regard to possible food limitation, so estimates are maxima. Although at least some zooplankton in the estuary are food-limited (Müller-Solger et al. 2002, Kimmerer et al. 2005b), data are insufficient to determine past levels of food limitation for the zooplankton considered here. Production of rotifers was estimated using a constant specific growth rate of $0.3 \mathrm{~d}^{-1}$ (Walz 1995). Production of juvenile calanoid copepods was based on development rate of Eurytemora affinis and Pseudodiaptomus forbesi determined experimentally at $15^{\circ} \mathrm{C}$ and egg development times determined at 10 to $20^{\circ} \mathrm{C}$ (author's unpubl. data), and literature data on relative weight per stage. Production of cyclopoid copepods was not calculated because of uncertainty in the identification of life stages in the monitoring data. Growth rate of mysids was estimated using relationships of specific growth rate to temperature for $\mathrm{Neo}$ mysis intermedia (Toda et al. 1984). These relationships were different for juveniles and adults. The IEP abundance data include number by length as well as total adults and other stages. I calculated the change in growth rate using the median length for transition to adult from all of the data $(9 \mathrm{~mm}$ for $N$. mercedis and $6 \mathrm{~mm}$ for Acanthomysis spp.), assuming that the adults were the largest animals in each sample. In addition I used data from Siegfried \& Kopache (1980) to estimate the fraction of mysid feeding based on animals: assuming that $3 \mathrm{~mm}$ and smaller mysids consumed no animals, I fit a straight line through the data for $7 \mathrm{~mm}$ and 11 mm mysids, which gave 100\% animal food for mysids larger than $15 \mathrm{~mm}$.

Consumption rate rather than growth rate was estimated for fish, since it could be readily estimated using the Wisconsin bioenergetics model (Hanson et al.
1997). Parameters were available for striped bass, herring, and Chinook salmon. Parameters for rainbow smelt did not appear suitable for smelt species in the SFE because consumption peaked at too low a temperature. Parameters for alewife were used for American and threadfin shad, and parameters for herring were used for northern anchovy. Other fish, none very abundant, were assigned parameters equal to those for striped bass.

Each of the climate variables was averaged for summer (June-October) and explored using autoregressive models and regression trees to detect step changes, then with linear models containing the step changes.

In all analyses, I applied graphical methods before selecting a statistical model for testing. Graphical examination of residuals was used to check for deviations from assumptions of the models applied. Statistical analyses used S-Plus v6.2 for Windows (Venables \& Ripley 1997). Error terms presented below are $95 \%$ confidence limits except where noted.

\section{RESULTS}

During the study period (1967 to 2003, 1980 to 2001 for statistical comparisons among taxa) mean summer freshwater outflow varied between 54 and $1152 \mathrm{~m}^{3} \mathrm{~s}^{-1}$, with droughts from 1976 to 1977 and from 1987 to 1992, and high-flow periods in 1983, 1995, and 1998 (Fig. 2A). Salinity varied between 3 and $18 \mathrm{psu}$ (median 12) at the western margin of Suisun Bay (Martinez), and 0.1 and 6 (median 1.3) at the eastern margin (Collinsville, Fig. 2B). Bivalve abundance in Suisun Bay was high during 1976 and 1977, and exceeded $100 \mathrm{~m}^{-2}$ in every year starting in 1987 (Fig. 2C). Mean chlorophyll concentration declined by about $70 \%$ around 1987 (Fig. 2D, Table 2). This decline was unrelated to freshwater flow or salinity, 2 proxy measures for climate effects (graphical analysis and linear regression, $p>0.1$ ). Calanoid copepod abundance declined more or less throughout the period, whereas cyclopoid abundance increased around 1980 and again in the early 1990s, the latter increase mainly comprising Limnoithona tetraspina.

Summer anchovy abundance declined sharply in the low-salinity region following the introduction of Corbula amurensis in 1987 (Fig. 3, Table 2). The decline in anchovy abundance occurred between 1987 and 1988 in the year-round survey (Fig. 3A) but between 1986 and 1987 in the fall survey (Fig. 3B). Note that chlorophyll concentration declined in $\sim$ July 1987, so this difference in the 2 surveys reflects the rapid response of the anchovies. In addition, the longer-term fall survey showed a period of low abundance during the drought 


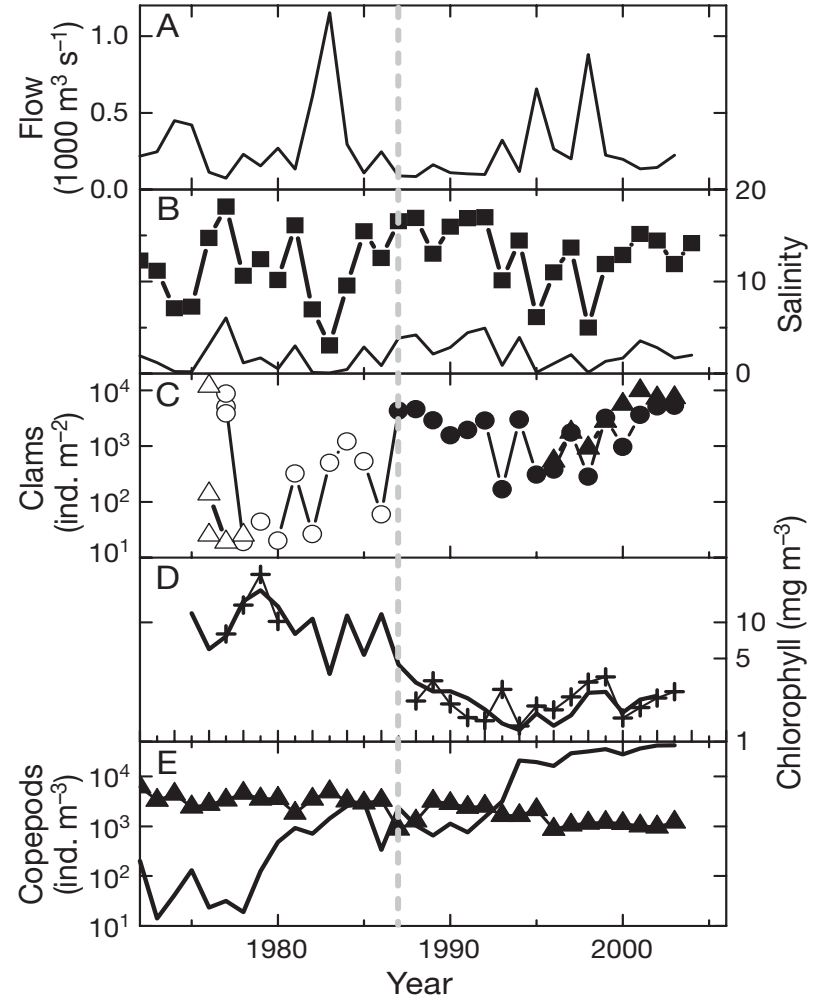

Fig. 2. Summer conditions in the low-salinity zone of the San Francisco Estuary. (A) Freshwater flow as net Delta outflow; (B) surface salinity at Martinez (squares, see Fig. 1) and Collinsville (line); (C) abundance of clams at stations in Grizzly Bay shoals (circles, see Fig. 1) and the main shipping channel (triangles), comprising Corbula amurensis, dominant from 1987 on (filled symbols), Mya arenaria, dominant during low-flow periods before 1987, and Corbicula fluminea, common during high-flow periods before 1987 (one of these species predominant when shown by open symbols; abundance over $2000 \mathrm{~m}^{-2}$ always $M$. arenaria); (D) chlorophyll concentration from 2 sampling programs: Interagency Ecological Program (solid line) and US Geological Survey (crosses); (E) copepod abundance for adultcalanoids (triangles) and cyclopoids

(solid line). Vertical dashed line: invasion of C. amurensis

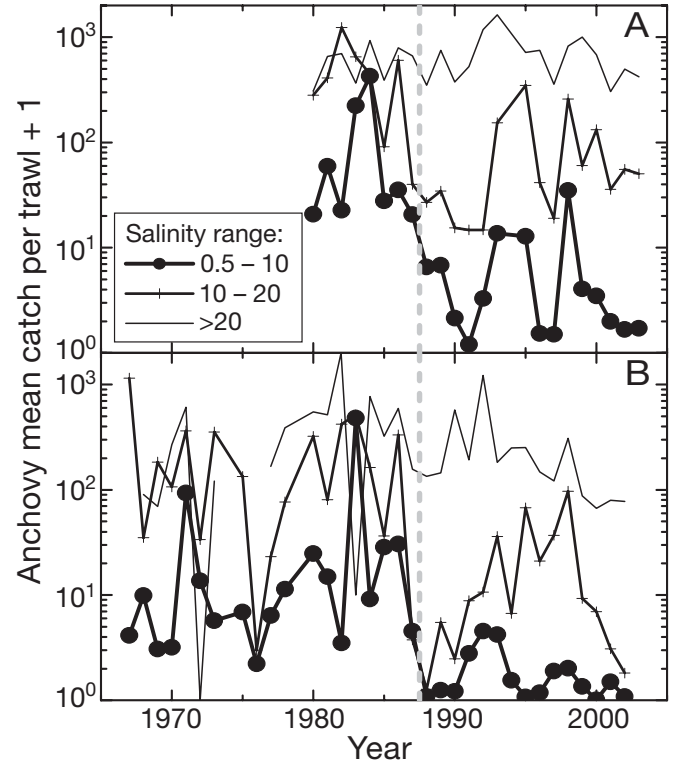

Fig. 3. Engraulis mordax. Mean catch per trawl (1 added to raw data) in 2 long-term monitoring programs during the summer dry season for 3 salinity ranges as determined by salinity samples taken at trawl stations. (A) Data from the IEP San Francisco Bay study (Table 1), which sampled throughout the estuary during most months; (B) the fall midwater trawl survey (Table 1), which sampled monthly from September to December (data used only through October) as far west as San Pablo Bay. Vertical dashed line: invasion of Corbula amurensis

of 1976 to 1977 and high abundance in 1983, a year of record-high freshwater flow. Abundance at intermediate salinity also declined after 1987-88 in both surveys and was low in 1976 and 1977 in the fall midwater trawl survey. Abundance at high salinity was variable but showed no similar step change in either survey. Some of the low and missing values from the fall survey occurred during high-flow periods (e.g. 1983) when the salt field had shifted seaward, and therefore

Table 2. Summary of regressions using step functions for chlorophyll from 3 sampling programs and anchovy catch per trawl from 2 sampling programs. All data were averaged across stations within the salinity band, then across months within the summer of each year. Data were fit with a regression tree to determine the first node, then fit with a step function at that node by ordinary least-squares regression. Step magnitudes are the antilogs of the regression parameter, i.e. the fraction that the post-step value was of the pre-step value, with antilog $95 \%$ confidence limits. Note that chlorophyll data from the USGS sampling program were missing for 1981-1987, so the year of the decline is uncertain. MWT: midwater trawl

\begin{tabular}{|c|c|c|c|c|c|c|}
\hline Variable & Source & Salinity range & Step between & $\begin{array}{l}\text { Step magnitude } \\
(95 \% \text { CL })\end{array}$ & $\begin{array}{c}\mathrm{N} \\
\text { before, after }\end{array}$ & $\mathrm{p}$ \\
\hline Chlorophyll & $\begin{array}{l}\text { IEP } \\
\text { DFG } \\
\text { USGS }\end{array}$ & $\begin{array}{l}0.6-10 \\
0.6-10 \\
0.6-10\end{array}$ & $\begin{array}{l}1987-88 \\
1986-87 \\
1988-89\end{array}$ & $\begin{array}{l}0.22(0.17-0.31) \\
0.26(0.18-0.36) \\
0.24(0.14-0.41)\end{array}$ & $\begin{array}{l}13,15 \\
12,15 \\
5,14\end{array}$ & $\begin{array}{l}<0.0001 \\
<0.0001 \\
<0.0001\end{array}$ \\
\hline $\begin{array}{l}\text { Anchovy } \\
\text { Catch + } 1\end{array}$ & $\begin{array}{l}\text { SF Bay } \\
\text { Study }\end{array}$ & $\begin{array}{c}0.6-10 \\
10-20 \\
>20\end{array}$ & $\begin{array}{l}1987-88 \\
1986-87\end{array}$ & $\begin{array}{l}0.08(0.03-0.22) \\
0.12(0.04-0.30)\end{array}$ & $\begin{array}{l}8,13 \\
7,14\end{array}$ & $\begin{array}{c}0.0002 \\
<0.0001 \\
>0.1\end{array}$ \\
\hline $\begin{array}{l}\text { Anchovy } \\
\text { Catch + } 1\end{array}$ & $\begin{array}{l}\text { MWT } \\
\text { Study }\end{array}$ & $\begin{array}{c}0.6-10 \\
10-20 \\
>20\end{array}$ & $\begin{array}{l}1986-87 \\
1986-87\end{array}$ & $\begin{array}{l}0.11(0.05-0.25) \\
0.07(0.02-0.19)\end{array}$ & $\begin{array}{l}18,15 \\
18,15\end{array}$ & $\begin{array}{c}<0.0001 \\
<0.0001 \\
>0.1\end{array}$ \\
\hline
\end{tabular}


the sampling program covered only the periphery of the population. The ratio of abundance at low salinity to that at high salinity also declined significantly in both surveys (Table 3).

There was no apparent change in length distribution of the anchovies with year in any of the 3 salinity ranges, nor was length related to salinity. The annual median wet biomass of northern anchovy for summer had a grand median of $1200 \mathrm{t}$ and 10th and 90th percentiles of 400 and 2000, respectively. An estimate of spawning biomass for July 1978 was $767 \mathrm{t}$ (McGowan 1986).

Abundance of northern anchovy at high salinity was unrelated to estimates of stock size in the coastal ocean (Fig. 4). Regressions had non-significant slopes for anchovy abundance in the Bay study vs. estimated biomass off central-southern California (slope $=-0.4 \pm 1.0$, $\mathrm{p}>0.1$ ), landings off central-southern California (slope $=-0.004 \pm 0.01, \mathrm{p}>0.1$ ), or catch in the rockfish survey off San Francisco Bay (Fig. 4C, slope $=0.1 \pm 0.6$, $\mathrm{p}>0.1$ ). The 2 highest values of abundance from the high-salinity region in the year-round survey (1992 and 1993) coincided with several of the lowest values of both catch and biomass of northern anchovy along the California coast. Landings of Pacific sardines in the coastal ocean increased steadily through the 1980s and 1990s, greatly exceeding anchovy landings, but catches of sardines in the high-salinity region of the estuary reached only $\sim 1 \%$ of the catches of anchovies in the same region (Fig. 4B).

The various measures of climate variability were unrelated to anchovy abundance in the high-salinity regions of the estuary (Fig. 5). Although anchovy abundance at high salinity was negatively related to the upwelling indices at both $36^{\circ} \mathrm{N}$ and $39^{\circ} \mathrm{N}$ (linear regression, slope and 95\% CL for $39^{\circ} \mathrm{N}=-0.01 \pm$ 0.007, df $=23, \mathrm{p}<0.01, \mathrm{r}^{2}=0.31$ ), this is opposite the sign expected. None of the indices was related to anchovy abundance in the low-salinity region. Furthermore, none of the indices had step changes close to 1987 (intervention analysis, $\mathrm{p}>0.3$ for all indices).

Table 3. Engraulis mordax. Summary statistics for ratios of abundance at low salinity $(0.6-10)$ to that at high salinity $(>20)$. Data for each year were log-transformed, and weighted means and standard deviations were calculated with the minimum number of data points as the weighting factor for each year. Missing years within each group occurred because surveys were not done or, in the case of the MWT study, no samples were taken at salinity $>20$. MWT: midwater trawl

\begin{tabular}{|lcccc|}
\hline Source & Year group & Geometric mean & CI & N (yr) \\
\hline SF Bay Study & $1980-1987$ & 0.09 & $0.04-0.22$ & 8 \\
& $1988-2003$ & 0.006 & $0.004-0.009$ & 15 \\
MWT Study & $1967-1987$ & 0.04 & $0.021-0.09$ & 15 \\
& $1988-2002$ & 0.01 & $0.007-0.015$ & 16 \\
\hline
\end{tabular}

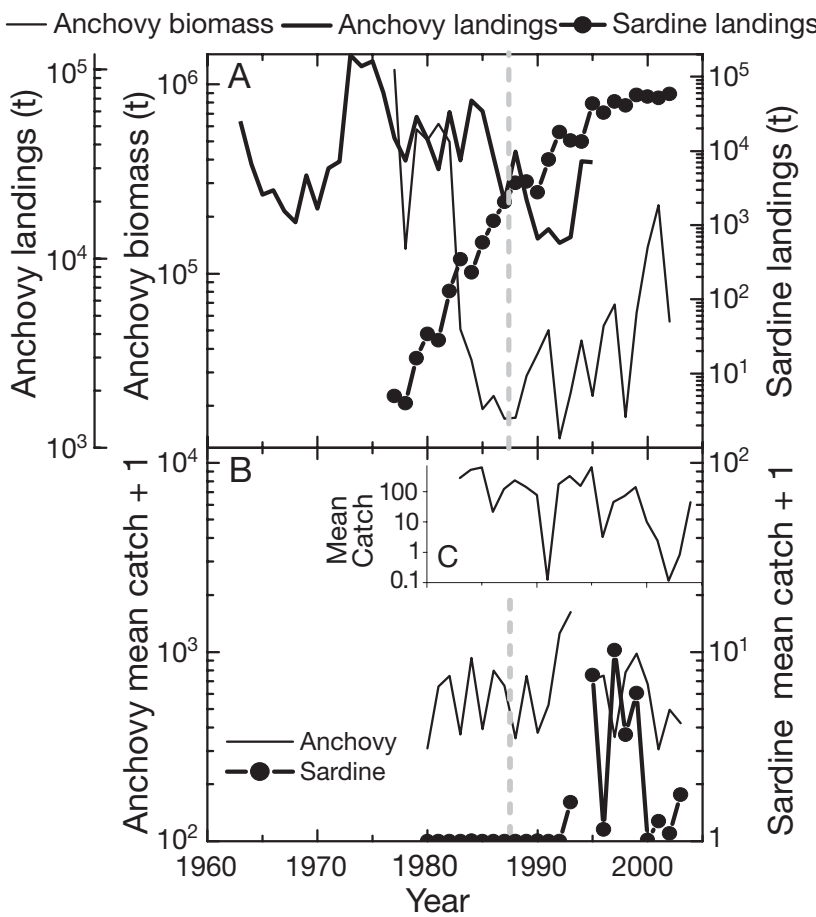

Fig. 4. Engraulis mordax and Sardinops sagax. (A) Measures of abundance in the coastal ocean including landings of anchovy in the California fishery and a biomass estimate based on egg counts; also landings of sardine (right axis, note difference in scales). (B) Catch per trawl as in Fig. 3A for anchovy and sardine (right axis) from salinity $>20 \mathrm{psu}$; (C) inset showing mean catch per trawl from a rockfish survey at stations in the coastal ocean near the mouth of San Francisco Bay (Ralston \& Howard 1995, S. Ralston, NOAA, pers. comm.). Vertical dashed line: invasion of Corbula amurensis

Within the low-salinity region of the estuary, mean summer biomass of several ecosystem components, corrected for freshwater flow, declined from 1980 to 1987, and 1988 to 2002 (Table 4). Phytoplankton biomass declined by $70 \%$, and this was reflected in the declines in biomass of rotifers and mysids, both of which underwent a long period of decline after 1987. However, mean biomass of calanoid and cyclopoid copepods did not change substantially, and declines in some species in summer were accompanied by increases in other, introduced species. Pseudodiaptomus forbesi replaced Eurytemora affinis (both calanoids) as the biomass dominant, and Limnoithona tetraspina became the biomass subdominant after 1993, replacing cyclopoid copepods that had declined after 1987. Bay shrimp underwent a period of low abundance during the drought of 1987 to 1992, but biomass overall did not change significantly between the 2 
time periods shown in Table 4. Anchovy biomass declined sharply and by a greater proportion than any other foodweb component. There were non-significant decreases in mean biomass of pelagic fish other than anchovies, and in demersal fish.

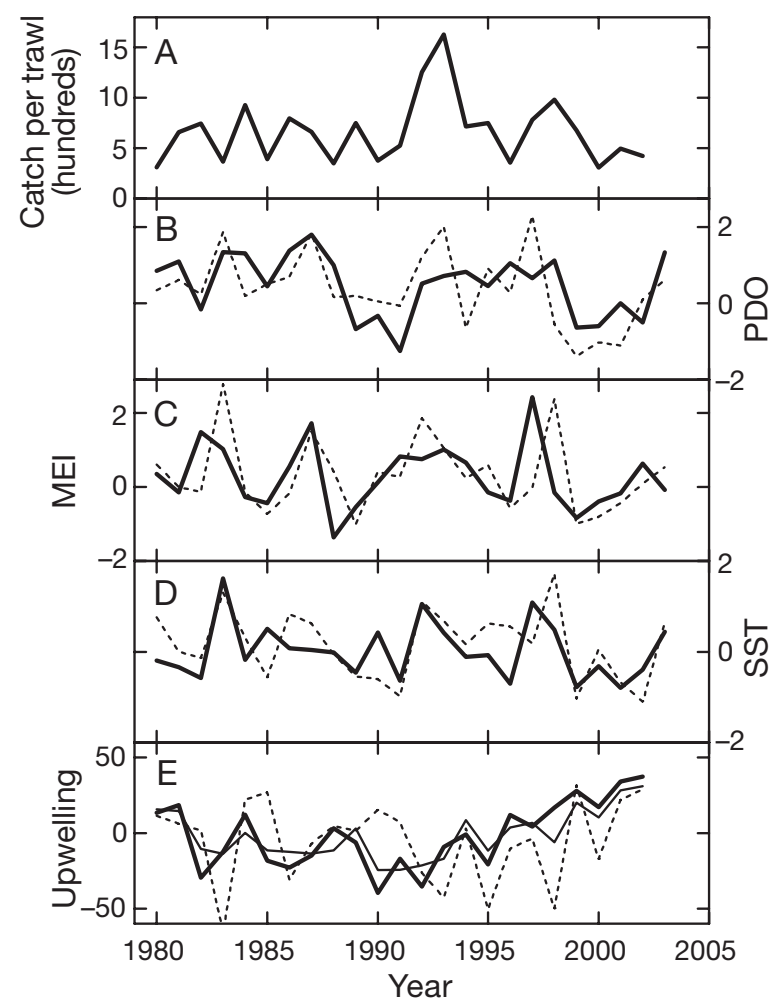

Fig. 5. Catch of northern anchovy in high-salinity region in summer, with several indices of climate variability for spring (dashed line) and summer (solid line). (A) Mean catch per trawl in the San Francisco Estuary at S $>20$; (B) Pacific Decadal Oscillation index (PDO; Mantua et al. 1997); (C) multivariate El Niño Southern Oscillation (ENSO) index (MEI; Wolter \& Timlin 1998); (D) reconstructed Sea Surface Temperature at $38^{\circ} \mathrm{N}, 122^{\circ} \mathrm{W}$ (SST; Smith \& Reynolds 2003); (E) upwelling index at $39^{\circ} \mathrm{N}$; also index for $36^{\circ} \mathrm{N}$, summer only (thin solid line) (Bakun 1990)
Placing these results in the context of the estuarine foodweb shows the overwhelming importance of the biomass of Corbula amurensis during the post-clam period (Fig. 6). Biomass data are unavailable for the microbial foodweb or the pre-clam bivalves, so this diagram is incomplete. Furthermore, given the assumptions required to calculate biomass of individual components, comparisons of biomass among components probably give only order-of-magnitude estimates. Nevertheless, this diagram illustrates the extent to which some components declined, while others did not.

Calculated production values for a subset of the foodweb followed those of biomass (Table 5). The decline in phytoplankton production was $62 \%$, somewhat less than that of biomass because of a compensating increase in water clarity in the latter period, due to reduced loading of inorganic particles during the extended drought (Kimmerer 2004). Production (and therefore presumably consumption) of mysids declined by about half, less than the decline in biomass because more of the mysids were small with a higher growth rate. Roughly $24 \%$ of the production of mysids was estimated to be based on consumption of animals, presumably mostly copepods. Consumption by anchovies declined about an order of magnitude, much more than did consumption by other pelagic and demersal fish (Table 5).

\section{DISCUSSION}

The decline in anchovy abundance in the low-salinity region of the San Francisco Estuary coincided with several system-wide events: besides the arrival of Corbicula amurensis, 1987 was an El Niño year (Fig. 5C) and a protracted drought was underway (Fig. 2). I argue below that the decline in anchovy abundance was unrelated to climate, but was simply a shift of the population away from a region that had become inhos-

Table 4. Summer biomass of foodweb components in Fig. 6 for the 2 time periods in the study, corrected for flow (i.e. partial residuals for the step change, with the grand mean added to restore units). Values in bold differ significantly between the 2 periods (analysis of covariance, $\mathrm{p}<0.05$ )

\begin{tabular}{|c|c|c|c|c|c|c|c|c|c|}
\hline $\begin{array}{l}\text { Time } \\
\text { period }\end{array}$ & $\begin{array}{l}\text { Phyto- } \\
\text { plankton }\end{array}$ & Rotifers & $\begin{array}{l}\text { Calanoid } \\
\text { copepods }\end{array}$ & $\begin{array}{l}\text { Cyclopoid } \\
\text { copepods }\end{array}$ & Mysids & Shrimp & Anchovies & $\begin{array}{l}\text { Other } \\
\text { pelagic }\end{array}$ & Demersal \\
\hline \multicolumn{10}{|l|}{$1980-1987$} \\
\hline $\begin{array}{l}\text { Geometric } \\
\text { mean }\end{array}$ & 208 & 5.1 & 8.3 & 1.4 & 9.2 & 16.3 & 5.2 & 2.7 & 6.4 \\
\hline $\mathrm{CL} \mathrm{mg} \mathrm{C} \mathrm{m}^{-3}$ & 130-332 & $3.9-6.8$ & $5.8-11.8$ & $0.7-2.8$ & $5.3-16.2$ & $10.9-24.4$ & $1.9-13.7$ & $1.6-4.5$ & $5.1-8.1$ \\
\hline \multicolumn{10}{|l|}{ 1988-2001 } \\
\hline $\begin{array}{l}\text { Geometric } \\
\text { mean }\end{array}$ & 62 & 1.1 & 6.2 & 1.3 & 2.5 & 9.7 & 0.3 & 1.7 & 4.3 \\
\hline $\mathrm{CL} \mathrm{mg} \mathrm{C} \mathrm{m}{ }^{-3}$ & $50-77$ & $0.7-1.8$ & $4.9-7.9$ & $0.7-2.5$ & $1.5-4.1$ & $7.5-12.6$ & $0.1-0.6$ & $1.4-2.0$ & $3.5-5.4$ \\
\hline
\end{tabular}




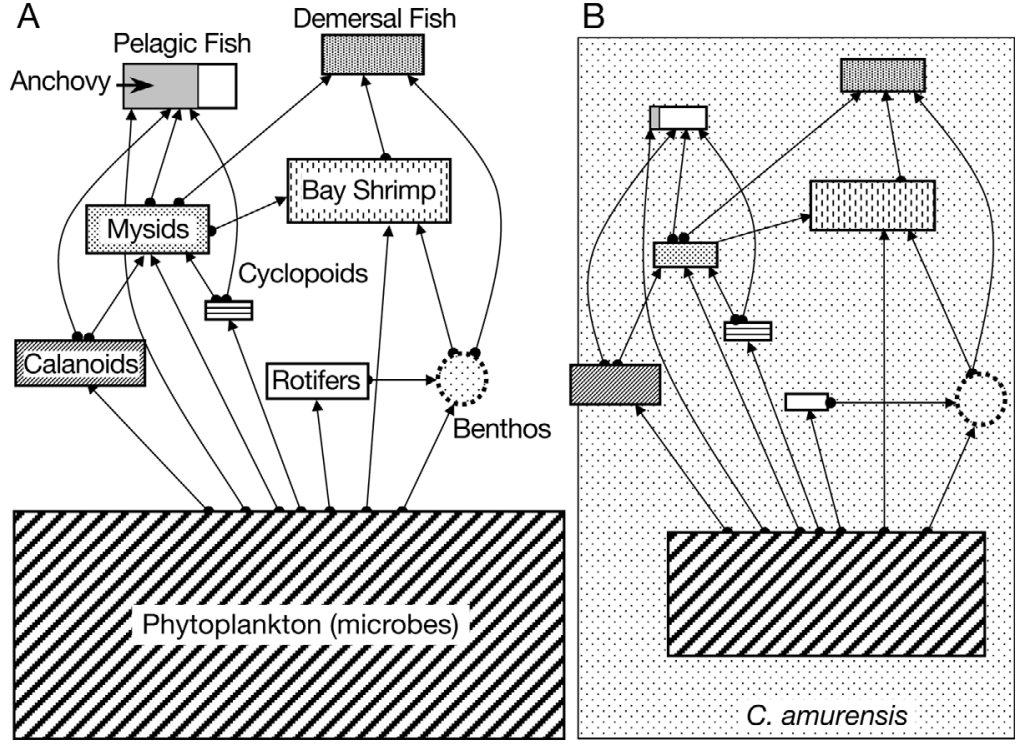

Fig. 6. Pelagic foodweb of the northern San Francisco Estuary. (A) Pre-clam conditions and (B) post-clam conditions, labels as in pre-clam conditions. Areas of boxes are proportional to estimated biomass (Table 4). Arrows indicate substantial energy flow as determined by gut content analyses or literature data. The area of the phytoplankton box is proportional to phytoplankton biomass only; other microbial biomass is unknown. An estimate of biomass of Corbula amurensis (J. Thompson, USGS, pers. comm.) is shown for the postclam period only (gray box in background), and the position of benthic bivalves in the foodweb is indicated by circles. Pelagic fish includes anchovies (gray part of box), which comprised a much greater proportion of pelagic fish biomass in the earlier than the later period

pitable. Such shifts are quite common, even familiar in terrestrial animals. In the lower Hudson River, several open-water fish species shifted seaward following a reduction in chlorophyll concentration due to the introduced zebra mussel, Dreissena polymorpha (Strayer et al. 2004). Similar behavioral shifts of northern anchovy in apparent response to chlorophyll concentration (or its covariates) have been noted off Baja California (Robinson 2004). Although increased mortality in the inhospitable region would result in a similar change in abundance, a behavioral shift in position is a simpler explanation that recognizes the ability of animals to move from unfavorable to favorable locations.

The decline in anchovy in regions of lower salinity in the estuary, but not at high salinity, occurred in striking coincidence with the decline in chlorophyll. The bulk of the anchovy population even before the decline was at high salinity: 95\% of the catch before 1987 occurred at $\mathrm{S}>10 \mathrm{psu}$. The relationship of abundance to salinity is presumably related to salinity stress, which would be exacerbated by poor feeding conditions. Thus the change in that relationship most likely occurred directly in response to food, since the regions of interest were defined by salinity (Fig. 3), and there has been no long-term change in salinity distribution within the estuary (Fig. 2). Furthermore, chlorophyll concentrations did not change appreciably in San Pablo Bay (Kimmerer 2004), a higher-salinity region where anchovy abundance remained high.

Anchovies feed by filtering or picking prey, switching between modes depending on prey availability and light (O'Connell 1972). Anchovies generally are considered zooplankton predators (Koslow 1981, Monteiro et al. 1991), but Engraulis mordax can feed on large phytoplankton cells such as diatoms (Chiappa-Carrara \& Gallardo-Cabello 1993). The Peruvian anchoveta E. ringens gets more of its energy from phytoplankton when it is filtering than when picking (Rojas de Mendiola 1971), and the Black Sea anchovy E. encrasicolius ponticus feeds predominantly on phytoplankton when zooplankton abundance is low (Bulgakova 1996). The phytoplankton biomass of the northern SFE consisted of about $54 \%$ cells larger than $22 \mu \mathrm{m}$ during 1980 (Cole et al. 1986), so much of the phytoplankton may have been available to anchovies. In recent years about 60 to $70 \%$ of the biomass has been smaller than $10 \mu \mathrm{m}$ (Kimmerer 2004). Furthermore, much of the decline in phytoplankton biomass was in diatoms (Lehman 2000, Kimmerer 2005). The total biomass of food available to anchovies in the low-salinity region declined with the phytoplankton, but without detailed information on the importance of phytoplankton in the diet of anchovies in the SFE it is impossible to measure the decline in total available food.

Anchovy abundance along the coast is generally associated with climate (Lluch-Belda et al. 1992, Chavez et al. 2003), but changes in abundance at a location may be due to shifts in spatial distribution as well as changes in population size (Rodriguez-Sanchez et al. 2002). The lack of association between anchovy biomass along the California coast and within the estuary may suggest a lack of coupling, or simply that variability in the estuary overwhelms that due to fluctuations in the coastal population. A key feature of pelagic fishes of coastal upwelling zones is the decadescale alternation of dominance between anchovies and sardines (Mantua et al. 1997). However, sardines are uncommon in the estuary (Fig. 4B), and it is apparent that these 2 species use the estuary very differently.

The climate indices were unrelated to anchovy abundance within the estuary except for the upwelling indices, but these had the wrong sign assuming that high anchovy abundance occurs during periods of low 
temperature in the coastal ocean (Chavez et al. 2003). This result could indicate that anchovies move from the coastal ocean into the estuary when upwelling conditions are unfavorable. Nevertheless, all of these results indicate that anchovies are responding differently to regional climate effects inside the estuary than along the coast. The lack of response (in either direction) of anchovy abundance at high salinity to the decrease in the PDO index in 1998-99 (Fig. 5B), which apparently caused an increase in anchovy abundance in the coastal ocean (Fig. 4A), suggests that linkages between the estuarine anchovy population and both climate and the coastal populations are weak. Furthermore, climate-related mechanisms for the decline at low salinity would require changes at high salinity to propagate to low salinity, whereas the change in abundance occurred only at low salinity.

Therefore the most parsimonious explanation for the decline in anchovy abundance in the low-salinity zone is as a direct or indirect response to the decline in chlorophyll. The decline in anchovy abundance roughly halved food consumption by all planktivorous fish (Table 5). In addition, the decline in mysid abundance further reduced consumption of copepods, although the data are inadequate to determine the magnitude of this effect. Mysid abundance continued to decline after 1987 (Kimmerer 2002, Fig. 4), but no subsequent increase was noted in copepod populations, suggesting a weak influence of mysids.

The declines in predator abundance may have allowed the copepods to maintain their abundance even with the reduced food supply (Fig. 6). That is, from a mass-balance perspective, with a reduced food supply the only possibility for the copepods to maintain their biomass was through lower losses to predation or other mortality. Furthermore, a greater proportion of zooplankton production became available to planktivorous fish other than anchovy.

The reduction in mortality could have arisen through a combination of reduced planktivore biomass due to the decline in anchovy and possibly mysid abundance, and a change in vulnerability of individual copepods to predation. Nearly all planktivorous fish in the upper estuary since the decline in anchovy are visual predators, and gelatinous zooplankton, which have various other feeding modes, are uncommon in the estuary (Orsi \& Mecum 1986, W. S. Kimmerer unpubl.). Since zooplankton differ in their abilities to either avoid or accommodate predation of different modes, the shift in the predatory environment may have facilitated, and may now maintain, a change in zooplankton species composition due originally to introductions. For example, the most abundant copepod in the brackish estuary is the introduced cyclopoid Limnoithona tetraspina, which does not feed on diatoms, has very low feeding and reproductive rates, and may be too small for effective consumption by visual planktivores (Bouley \& Kimmerer 2006). The current situation of low diatom production and low consumption by non-visual planktivores should favor this species.

The results reported herein have broad implications for ecosystem modeling studies. Spatially detailed model ecosystems show rich arrays of behaviors involving the interaction between component movements among spatial cells and processes within cells (Blasius et al. 1999). Nevertheless, models of energy flow in complex foodwebs do not generally consider loss of some foodweb components when conditions change (Baird \& Ulanowicz 1989, McCann et al. 1998). Aquatic foodwebs tend to be complex, having weak interactions (Strong 1992) that may make them stable (McCann et al. 1998). Their responses to significant perturbations can be strong but are rarely straightforward (Vanni \& Layne 1997). Which species are in the food web can be as important as how many there are (Downing \& Leibold 2002). Therefore, speciesspecific responses of zooplankton (Runge 1988) or fish (Stein et al. 1995) may cause different systems to respond in different ways to the same perturbation. This study shows that behavioral shifts in spatial distribution of a key species are an additional mechanism by which aquatic foodwebs can accommodate change.

Acknowledgements. I thank W. Bennett, J. Cloern, J. Durand, A. Jahn, R. Larson, F. Nichols, and S. Obrebski for comments on earlier drafts, J. Thompson for helpful discussions and data, and S. Ralston for data on anchovy catches. I acknowledge funding from the Interagency Ecological Program and CALFED contract ERP-99-N09.

\section{LITERATURE CITED}

Alpine AE, Cloern JE (1992) Trophic interactions and direct physical effects control phytoplankton biomass and production in an estuary. Limnol Oceanogr 37:946-955

Armor C, Herrgesell PL (1985) Distribution and abundance of fishes in the San Francisco Bay estuary between 1980 and 1982. Hydrobiologia 129:211-227

Baird D, Ulanowicz RE (1989) The Seasonal dynamics of the Chesapeake Bay ecosystem. Ecol Monogr 59:329-364

Bakun A (1990) Global climate change and intensification of coastal ocean upwelling. Science 247:198-201

Blasius B, Huppert A, Stone L (1999) Complex dynamics and phase synchronization in spatially extended ecological systems. Nature 399:354-359

Bouley P, Kimmerer WJ (2006) Ecology of a highly abundant, introduced cyclopoid copepod in a temperate estuary. Mar Ecol Prog Ser 324:219-228

Bulgakova YV (1996) Feeding in the Black Sea anchovy: diet composition, feeding behaviour, feeding periodicity and daily rations. Sci Mar 60:283-284

Burkill PH, Kendall TF (1982) Production of the copepod Eurytemora affinis in the Bristol Channel. Mar Ecol Prog Ser 7:21-31 
California Department of Fish and Game (CDFG) (2002) Review of some California fisheries for 2001: market squid, sea urchin, dungeness crab, lobster, prawn, abalone, groundfish, swordfish and shark, coastal pelagic finfish, ocean salmon, nearshore live-fish, Pacific herring, white seabass, and kelp. California Cooperative Oceanic Fisheries Investigations Reports 43:13-30

California Department of Fish and Game (CDFG) (2003) Review of some California fisheries for 2002: market squid, sea urchin, dungeness crab, prawn, coastal pelagic finfish, albacore, ocean salmon, nearshore live-fish, Pacific herring, and recreational. California Cooperative Oceanic Fisheries Investigations Reports 44:10-27

Carpenter SR, Chisholm SW, Krebs CJ, Schindler DW, Wright RF (1995) Ecosystem experiments. Science 26: 324-327

Chavez FP, Ryan J, Lluch-Cota SE, Niquen CM (2003) From anchovies to sardines and back: multidecadal change in the Pacific Ocean. Science 299:217-221

Chiappa-Carrara X, Gallardo-Cabello M (1993) Feeding behavior and dietary composition of the northern anchovy, Engraulis mordax Girard (Pisces: Engraulidae), off Baja California, Mexico. Cienc Mar 19:285-305

Cloern JE (1982) Does the benthos control phytoplankton biomass in south San Francisco Bay (USA)? Mar Ecol Prog Ser 9:191-202

Cloern J, Alpine A, Cole B, Wong R, Arthur J, Ball M (1983) River discharge controls phytoplankton dynamics in the northern San Francisco Bay estuary. Estuar Coast Shelf Sci 16:415-429

Coan EV (2002) The eastern Pacific Recent species of the Corbulidae (Bivalvia). Malacologia 44:47-105

Cole BE, Cloern JE (1984) Significance of biomass and light availability to phytoplankton productivity in San Francisco Bay. Mar Ecol Prog Ser 17:15-24

Cole BE, Cloern JE, Alpine AE (1986) Biomass and productivity of three phytoplankton size classes in San Francisco Bay. Estuaries 9:117-126

Downing AL, Leibold MA (2002) Ecosystem consequences of species richness and composition in pond food webs. Nature 416:837-841

Gonzalez MJ, Downing A (1999) Mechanisms underlying amphipod responses to zebra mussel (Dreissena polymorpha) invasion and implications for fish-amphipod interactions. Can J Fish Aquat Sci 56:679-685

Hanson PC, Johnson TB, Schindler DE, Kitchell JF (1997) Fish bioenergetics 3.0. University of Wisconsin Sea Grant Institute, Madison, WI

Hutchinson A (1982) Plankton studies in San Francisco Bay. 3. Zooplankton species composition and abundance in the South Bay, 1980-81. Report No. Open File Report 82-1002, US Geological Survey, Menlo Park, CA

Jacobson LD, Lo NCH, Herrick SF Jr, Bishop T (1995) Spawning biomass of the northern anchovy in 1995 and status of the coastal pelagic fishery during 1994. Report No. Administrative Report LJ-95-11, National Marine Fisheries Service Southwest Fisheries Science Center, La Jolla, CA

Jassby AD, Kimmerer WJ, Monismith SG, Armor C, Cloern JE, Powell TM, Schubel JR, Vendlinski TJ (1995) Isohaline position as a habitat indicator for estuarine populations. Ecol Appl 5:272-289

Jassby AD, Cloern JE, Cole BE (2002) Annual primary production: patterns and mechanisms of change in a nutrientrich tidal estuary. Limnol Oceanogr 47:698-712

Jones CG, Lawton JH, Shackak M (1994) Organisms as ecosystem engineers. Oikos 69:373-386
Kimmerer WJ (2002) Effects of freshwater flow on abundance of estuarine organisms: physical effects or trophic linkages? Mar Ecol Prog Ser 243:39-55

Kimmerer WJ (2004) Open water processes of the San Francisco Estuary: from physical forcing to biological responses. San Francisco Estuary and Watershed Science (Online Serial) Vol. 2, Issue 1, Article 1. http://repositories.cdlib.org/jmie/ sfews/vol2/iss1/art1

Kimmerer WJ (2005) Long-term changes in apparent uptake of silica in the San Francisco estuary. Limnol Oceanogr 50: 793-798

Kimmerer WJ, McKinnon AD (1987) Growth, mortality, and secondary production of the copepod Acartia tranteri in Westernport Bay, Australia. Limnol Oceanogr 32:14-28

Kimmerer WJ, Orsi JJ (1996) Causes of long-term declines in zooplankton in the San Francisco Bay estuary since 1987. In: Hollibaugh JT (ed) San Francisco Bay: the ecosystem. AAAS, San Francisco, p 403-424

Kimmerer WJ, Avent SR, Bollens SM, Moyle PB, Nobriga M, Visintainer T (2005a) Variability in length-weight relationships used to estimate biomass of estuarine fishes from survey data. Trans Am Fish Soc 134:481-495

Kimmerer WJ, Nicolini MH, Ferm N, Peñalva C (2005b) Chronic food limitation of egg production in populations of copepods of the genus Acartia in the San Francisco Estuary. Estuaries 28:541-550

Klein Breteler WCM, Fransz HG, Gonzalez SR (1982) Growth and development of four calanoid copepod species under experimental and natural conditions. Neth J Sea Res 16: 195-207

Koslow JA (1981) Feeding selectivity of schools of northern anchovy, Engraulis mordax, in the Southern California Bight. Fish Bull 79:131-142

Lehman PW (2000) The influence of climate on phytoplankton community biomass in San Francisco Bay Estuary. Limnol Oceanogr 45:580-590

Lluch-Belda D, Schwartzlose RA, Serra R, Parrish R, Kawasaki T, Hedgecock D, Crawford RJM (1992) Sardine and anchovy regime fluctuations of abundance in four regions of the world oceans: a workshop report. Fish Oceanogr 1:339-347

Mantua NJ, Hare SR, Zhang Y, Wallace JM, Francis RC (1997) A Pacific interdecadal climate oscillation with impacts on salmon production. Bull Am Meteorol Soc 78:6

Mayer CM, Van DeValk AJ, Forney JL, Rudstam LG, Mills EL (2000) Response of yellow perch (Perca flavescens) in Oneida Lake, New York, to the establishment of zebra mussels (Dreissena polymorpha). Can J Fish Aquat Sci 57:742-754

McCann K, Hastings A, Huxel GR (1998) Weak trophic interactions and the balance of nature. Nature 365:794-798

McGowan MF (1986) Northern anchovy, Engraulis mordax, spawning in San Francisco Bay, California, 1978-79, relative to hydrography and zooplankton prey of adults and larvae. Fish Bull 84:879-893

Monteiro PMS, James AG, Sholto-Douglas AD, Field JG (1991) The ${ }^{13} \mathrm{C}$ trophic position isotope spectrum as a tool to define and quantify carbon pathways in marine food webs. Mar Ecol Prog Ser 78:33-40

Moyle P, Daniels R, Herbold B, Baltz D (1986) Patterns in distribution and abundance of a noncoevolved assemblage of estuarine fishes in California. Fish Bull 84: 105-117

Müller-Solger AB, Jassby AD, Müller-Navarra D (2002) Nutritional quality of food resources for zooplankton (Daphnia) in a tidal freshwater system (Sacramento-San Joaquin River Delta). Limnol Oceanogr 47:1468-1476 
Nichols FH (1985) Increased benthic grazing: an alternative explanation for low phytoplankton biomass in northern San Francisco Bay during the 1976-1977 drought. Estuar Coast Shelf Sci 21:379-388

Noonburg EG, Shuter BJ, Abrams PA (2003) Indirect effects of zebra mussels (Dreissena polymorpha) on the planktonic food web. Can J Fish Aquat Sci 60:1353-1368

O'Connell CP (1972) The interrelation of biting and filtering in the feeding activity of the northern anchovy (Engraulis mordax). J Fish Res Board Can 29:285-293

Orsi J, Mecum W (1986) Zooplankton distribution and abundance in the Sacramento-San Joaquin Delta in relation to certain environmental factors. Estuaries 9:326-339

Orsi JJ, Ohtsuka S (1999) Introduction of the Asian copepods Acartiella sinensis, Tortanus dextrilobatus (Copepoda: Calanoida), and Limnoithona tetraspina (Copepoda: Cyclopoida) to the San Francisco Estuary, California, USA. Plankton Biol Ecol 46:128-131

Phelps HL (1994) The Asiatic clam (Corbicula fluminea) invasion and system-level ecological change in the Potomac River Estuary near Washington, DC. Estuaries $17: 614-621$

Prins TC, Smaal AC, Dame RF (1998) A review of the feedbacks between bivalve grazing and ecosystem processes. Aquat Ecol 31:349-359

Ralston S, Howard DF (1995) On the development of yearclass strength and cohort variability in two northern California rockfishes. Fish Bull 93:720-720

Ricciardi A, Bourget E (1998) Weight-to-weight conversion factors for marine benthic macroinvertebrates. Mar Ecol Prog Ser 163:245-251

Robinson CJ (2004) Responses of the northern anchovy to the dynamics of the pelagic environment: identification of fish behaviours that may leave the population under risk of overexploitation. J Fish Biol 64:1072-1087

Rodriguez-Sanchez R, Lluch-Belda D, Villalobos H, OrtegaGarcia S (2002) Dynamic geography of small pelagic fish populations in the California Current System on the regime time scale. Can J Fish Aquat Sci 59:1980-1988

Rojas de Mendiola B (1971) Some observations on the feeding of the Peruvian anchoveta Engraulis ringens J. in two regions of the Peruvian coast. In: Costlow JD Jr (ed) Fertility of the sea, Vol 2. Gordon \& Breach, New York, p 417-425

Runge JA (1988) Should we expect a relationship between primary production and fisheries? The role of copepod dynamic as a filter of trophic variability. Hydrobiologia 167/168:61-71

Schwartzlose RA, Alheit J, Bakun A, Baumgartner TR and 17 others (1999) Worldwide large-scale fluctuations of sardine and anchovy populations. S Afr J Mar Sci 21:289-347
Siegfried C, Kapache M (1980) Feeding of Neomysis mercedis (Holmes). Biol Bull 159:193-205

Smith TM, Reynolds RW (2003) Extended reconstruction of global sea surface temperatures based on COADS data (1854-1997). J Clim 16:1495-1510

Stein RA, DeVries DR, Dettmers JM (1995) Food-web regulation by a planktivore: exploring the generality of the trophic cascade hypothesis. Can J Fish Aquat Sci 52: $2518-2526$

Strayer DL, Hattala KA, Kahnle AW (2004) Effects of an invasive bivalve (Dresseina polymorpha) on fish in the Hudson River estuary. Can J Fish Aquat Sci 61:924-941

Strong DR (1992) Are trophic cascades all wet? Differentiation and donor-control in speciose ecosystems. Ecology 73: $747-754$

Thompson JK (2000) Two stories of phytoplankton control by bivalves in San Francisco Bay: the importance of spatial and temporal distribution of bivalves. J Shellfish Res 19: 612

Toda H, Takahashi M, Ichimura S (1984) The effect of temperature on the post-embryonic growth of Neomysis intermedia Czerniawsky (Crustacea, Mysidacea) under laboratory conditions. J Plankton Res 6:647-662

Uye S (1982) Length-weight relationships of important zooplankton from the Inland Sea of Japan. J Oceanogr Soc Jpn 38:149-158

Uye SI, Iwai Y, Kasahara S (1983) Growth and production of the inshore marine copepod Pseudodiaptomus marinus in the central part of the Inland Sea of Japan. Mar Biol 73: 91-98

Vanderploeg HA, Nalepa TF, Jude DJ, Mills EL, Holeck KT, Liebig JR, Grigorovich IA, Ojaveer H (2002) Dispersal and emerging ecological impacts of Ponto-Caspian species in the Laurentian Great Lakes. Can J Fish Aquat Sci 59: $1209-1228$

Vanni MJ, Layne CD (1997) Nutrient recycling and herbivory as mechanisms in the 'top-down' effect of fish on algae in lakes. Ecology 78:21-40

Venables WN, Ripley BN (1997) Modern applied statistics with S-plus. Springer-Verlag, New York

Vrooman AM, Paloma PA, Zweifel JR (1981) Electrophoretic, morphometric, and meristic studies of subpopulations of northern anchovy, Engraulis mordax. Calif Fish Game 67: $39-51$

Walz N (1995) Rotifer populations in plankton communities: energetics and life history strategies. Experientia 51: 437-453

Wolter K, Timlin MS (1993) Monitoring ENSO in COADS with a seasonally adjusted principal component index. Proc 17th Clim Diag Works, Norman, OK, pp 52-57

Submitted: August 12, 2005; Accepted: March 21, 2006

Proofs received from author(s): September 6, 2006
Editorial responsibility: Otto Kinne (Editor-in-Chief), Oldendorf/Luhe, Germany 